\title{
KETERAMPILAN MANAJERIAL KEPALA SEKOLAH
}

\author{
JAMALUDDIN ISKANDAR \\ Fakultas Tarbiyah dan Keguruan \\ Universitas Islam Negeri Alauddin Makassar
}

\begin{abstract}
:
This paper aims to reveal the technical principal's managerial skills and factors that support and inhibit. It focuses on two main issues, namely: (1) What is the principal's managerial skills in terms of: Conceptual skills, Administrative skills, Human relationship skills, and. The concept of the principal leads to the Vision of the School Mission, and implements the open managerial concept in its management. The principal always cooperates, coordinated with all related elements and always gives motivation to the teachers and learners. Monitoring, evaluating and evaluating and constantly controlling school equipment. Factors that support the principal's managerial skills are all stakeholders in the school including; teachers, students, administrators, and society.
\end{abstract}

Keywords: Principal, Management

\section{LATAR BELAKANG}

ntuk mencapai tujuan pendidikan pemimpin atau kepala sekolah harus mempunyai keterampilan untuk dapat melaksanakan fungsi-fungsinya dan tugas-tugasnya, maka para manajer membutuhkan berbagai kemampuan dan keterampilan dasar yaitu: keterampilan membuat konsep (conceptual skill), keterampilan melaksanakan administrasi (administrative skill), keterampilan bekerja sama (human relationship skill), dan keterampilan melaksanakan secara teknis (technical skill). Keempat keterampilan manajerial tersebut, diperlukan untuk melaksanakan tugas manajerial secara efektif (Amin, 1993:9-10). Oleh karna itu, pengelolaan pendidikan memerlukan pemimpin yang potensial dan kompetensi sehingga seluruh pengelolaan pendidikan dapat melaksanakan tugas dan fungsinya sesuai dengan target yang telah ditetapkan.

Keberhasilan suatu lembaga pendidikan memerlukan orang-orang yang mampu memimpin sekolah dan profesional dalam bidang kependidikan (Wahyudi, 2012:63). Kepemimpinan kepala sekolah merupakan salah satu faktor yang dapat mendorong sekolah terebut untuk dapat mewujudkan visi, misi, tujuan dan sasaran melalui program sekolah yang dilaksanakan secara terencana dan bertahap. Atas dasar latar belakang diatas maka tulisan ini dipokuskan kepada Keterampilan Menejerial Kepalah Sekolah.

\section{RUMUSAN MASALAH}

Berdasarkan latar belakang tersebut, fokus dalam tulisan ini sebagai berikut:

1. Bagaimana keterampilan manajerial Kepala sekolah 
2. Faktor-faktor apa saja yang mendukung dan menghambat keterampilan menejerial kepala sekolah.

\section{TINJAUAN TEORITIS}

\section{Pengertian Keterampilan Manajerial}

Secara etimologi, istilah keterampilan berasal dari bahasa Inggris yaitu skill, yang artinya kemahiran atau kecakapan. Secara terminologi keterampilan adalah kemampuan dalam melaksanakan tugas berdasarkan kompetensi pekerjaan dan hasilnya dapat diamati.

Keterampilan-keterampilan manajerial diperlukan untuk melaksanakan tugas manaajerial secara efektif akan tetapi jenis keterampilan berbeda menurut tingkat manajer dalam organisasi (Wahyudi, 2012: 68).

Manajer memegang kendali yang amat penting dalam mewujudkan efektifitas organisasi. Seberapa jauh organisasi mencapai tujuannya dan memenuhi kebutuhan masyarakat, sangat bergantung pada baik tidaknya manajer organisasi yang bersangkutan mengoperasikan pekerjaannya. Ketika manajer tidak baik dalam mengoperasikan pekerjaannya, niscaya organisasi tersebut tidak akan berhasil mencapai tujuannya dengan baik.

\section{Manfaat Keterampilan Manajerial}

Segala sesuatu yang diciptakan oleh Allah Swt. tentu memiliki manfaat masingmasing, bagitu pula dengan ilmu. Ilmu yang harus dipelajari seorang pemimpin salah satunya adalah ilmu manajemen. IImu manajemen memiliki fungsi dan manfaatnya sendiri bagi setiap orang yang mempelajarinya. Begitu pula dengan manfaat keterampilan manajerial, adapun manfaat keterampilan manajerial di antaranya, yaitu:

1. Untuk dapat mengetahui dan mengaplikasikan apa saja tugas pokok yang harus dijalankan sebagai seorang pemimpin.

2. Untuk dapat berinteraksi atau berkomunikasi dengan orang lain baik yang berada dalam organisasi maupun di luar organisasi.

3. Untuk dapat mengembangkan berfikir abstrak.

4. Untuk dapat mendeteksi kemungkinan yang akan dihadapinya, dan

5. Untuk dapat meneliti baik buruknya suatu permasalahan sampai pada tahap pengambilan keputusan yang tepat dalam periode kepemimpinannya.

\section{Jenis-jenis Keterampilan Manajerial}

Untuk menjadi kepala sekolah yang berhasil harus memilki keterampilan atau keahlian dasar (Wahyudi, 2012:69). Terdapat tiga bidang keterampilan manajerial yang perlu dikuasai oleh manajer dan akan dibahas lebih dalam di antaranya:

1. Keterampilan Konseptual (conceptual skill)

2. Keterampilan Administrasi (admistrative skill) 
3. Keterampilan Manusiawi (human relationship skill)

4. Keterampilan Tehnik (technical skill)

\section{a. Keterampilan Konseptual (Conceptual Skill)}

Keterampilan konseptual (conceptual skill) yaitu keterampilan yang harus dimiliki oleh kepala sekolah untuk menentukan strategi, merencanakan, merumuskan kebijakan, serta memutuskan suatu yang terjadi dalam organisasi termasuk sekolah sebagai lembaga pendidkan. Untuk maksud tersebut para manajer pendidikan memerlukan konsep-konsep yang didasarkan pada pemahaman tentang organisasi, cara mengatasi masalah, dan mempertahankan, serta meningkatkan perkembangan organisasi. Maka kemampuan para manajer pada umumnya terutama manajer seharusnya memiliki kemampuan yang cukup memadai dalam membuat perencanaan pendidikan secara komprehenshif, terpadu dan ekonomis. Dengan kemampuan tersebut, pada gilirannya dapat memberikan efek yang positif pula terhadap setiap usaha untuk meningkatkan mutu keluaran lembaga pendidikan (Wahyudi, 2012:70).

Untuk mewujudkan keahlian konseptual seorang pemimpin sekolah atau Madrasah harus memiliki mental kepribadian yang unggul diperoleh dari keyakinan atau aturan-aturan agama yang diyakini. Selain itu, seorang pemimpin memerlukan keterampilan intrapersonal, dan kemampuan yang lebih mendalam akan ilmu pengetahuan yang diperlukannya secara menyeluruh sehingga akan mampu mengonsep suatu program yang unggul serta mampu menciptakan kepemimpinan yang efektif, di ataranya yaitu:

1. Kemampuan intrapersonal adalah kemapuan seseorang menerima informasi, mengelola, menyimpan, dan menghasilkan kembali. Proses pengelolaan informasi ini disebut komunikasi intrapersonal.

2. penguasaan pengetahuan secara holistik

Seorang pemimpin agar dapat melaksanakan tugasnya dengan baik dan optimal harus memiliki ilmu pengetahuan yang luas dan komprehensif. Di antara ilmu pengetahuan yang dimiliki kepala sekolah sebagai seorang pemimpin selain kemampuan pedagogik sebagai tugas utama seorang pendidik, tentunya perlu pemahaman dalam ilmu pengetahuan lainya. IImu pengetahuan penunjang yang harus dimiliki di antaranya yaitu ilmu pengetahuan tentang: keagamaan, hukum atau perundang-undangan (khususnya tentang pendidikan), kepemimpinan, manajemen keuangan, manajemen pemasaran, serta perilaku organisasional (Helmawati, 2014:112-125).

3. Kemampuan sifat dan mental pemimpin.

Seorang kepala sekolah atau madrasah hendaknya memiliki sifat kestabilan dan kemampuan mental. Kestabilan ini mencakup kestabilan dalam tingkah laku, pandangan hidup, dan kestabilan dalam nilai-nilai yang dianut. Kestabilan dalam perilaku berarti bahwa sesesorang yang segala perbuatanya dan tingkah lakunya 
senantiasa berdasarkan atas suatu rencana yang telah dipikirkan (dikonsep) dan dipertimbangkan secara matang. Kestabilam di sini bukanlah dalam pengertian yang kaku atau tidak dapat di ubah, tetapi kestabilan dinamis. Maksudnya adalah perilaku dapat berubah meskipun sudah direncanakan, tetapi perubahan ini didasarkan pada pertimbangan-pertimbangan yang rasional (Helmawati, 2014:138-142).

\section{b. Keterampilan Administrasi (Administrative Skill)}

Secara sederhana administrasi berasal dari kata Latin "ad" dan "ministro". Ad mempunyai arti "kepada" dan ministro berarti "melayani". Secara bebas dapat diartikan bahwa administrasi itu merupakan pelayanan atau pengabdian terhadap subjek tertentu.

Keterampilan administrasi (administrative skill) yaitu keseluruhan proses keterampilan bekerja sama dengan memanfaatkan dan memberdaya segala sumber yang tersedia melalui aktivitas perencanaan, pengorganisasian, pengendalian, penggerakkan, pemotivasian, penyusunan kepegawaian, pengawasan dan supervisi, serta penilaian untuk mewujudkan sistem pendidikan yang efektif dan efesien dan berkualitas (Engkoswara dan Komariah, 2010:52).

\section{c. Keterampilan Manusiawi (Human Relationship skill)}

Keterampilan manusiawi (human relationship skill) adalah kemampuan mengembangkan hubungan yang harmonis dengan semua anggota lembaga atau organisasi. Keterampilan ini didemostrasikan dalam cara seorang manajer berhubungan dengan orang lain, termasuk kemampuan untuk memotivasi, pemberian sarana, koordinasi, bimbingan, komunikasi, dan memecahkan konflik (Draf, 2002:17).

\section{d. Keterampilan Tehnik (Technical Skill)}

Keterampilan teknis (technical skill) yaitu kemampuan untuk menggunakan pengetahuan, metode-metode, prosedur, tehnik dan akal yang diperlukan untuk melaksanakan tugas spesifik yang diperoleh lewat pengalaman, pendidikan, dan pelatihan (Kamaluddin dan Alfan, 2012:161).

Adapun bentuk kegiatan kepala sekolah yang bersifat teknis adalah sebagai berikut:

1) Kepala sekolah menjalankan supervisi kepada guru di kelas,

2) Kepala sekolah mengevaluasi dan merevisi program pengajaran guru,

3) Kepala sekolah membuat program pelaksanaan kegiatan pengajaran dengan menghubungkan kurikulum dengan waktu, fasilitas, dan personel yang ada,

4) Kepala sekolah mengelola program evaluasi siswa,

5) Mengkoordinir penggunaan alat pengajaran,

6) Membantu guru dalam perbaikan pengajaran, 
7) Membantu guru dalam mengdiagnosis kesulitan belajar siswa

8) Mengatur dan mengawasi tata tertib siswa,

9) Menyusun anggaran belanja sekolah,

10) Melaksanakan aadministrasi sekolah yang menjadi tanggungjawabnya.

Pada akhirnya dapat disimpulkan bahwa, keterampilan tehnikal yang perlukan oleh kepala sekolah adalah yang erat kaitannya dengan aplikasi pengetahuan tentang cara pengelolaan kelas pengunaan metode pengajaran, tehnik evaluasi siswa, tehnik pembuatan satuan acara pembelajaran, tehnik-tehnik pengelolaan sarana dan prasarana pendidikan, serta tehnik mengarahkan dan membina para guru di sekolah.

Kepala sekolah dalam menjalankan tugas mempunyai peran ganda sebagai administrator, sebagai pemimpin, dan sebagai supervaisor, pendidikan. Terdapat empat keterampilan harus dimiliki oleh setiap pemimpin pada level administrasi atau manajemen apapun yaitu: keterampilan konseptual (conceptual skill), keterampilan administrative skill, keterampilan hubungan dengan manusia (human realtionship skill), berkenaan dengan kemampuan bekerjasama dengan orang lain, pemberian motivasi kepada setiap individu, dan menerapkan kepemimpinan efektif. Serta keterampilan tahnik (technical skill), berkenaan dengan know how dalam melaksanakan tugas sehari-hari, baik teknis edukatif maupun administratif.

\section{Kepala Sekolah Sebagai Manajer}

Dalam rangka melakukan peran dan fungsinya sebaagi manajer, kepala sekolah harus memiliki strategi yang tepat untuk mendayagunakan tenaga kependidikan melalui kerjasama atau kooperatif, memberi kesempatan kepada para tenaga kependidikan untuk meningkatkan profesinya, dan mendorong keterlibatan seluruh tenaga kependidikan dalam berbagai kegiatan yang menunjang program Sekolah.

\section{PEMBAHASAN}

\section{Keterampilan Manajerial Kepala Sekolah}

\section{Keterampilan konseptual (Conceptual Skill)}

Keterampilan konseptual (conceptual skill) yaitu keterampilan yang harus dimiliki oleh kepala sekolah untuk menentukan strategi, merencanakan, merumuskan kebijakan, serta memutuskan sesuatu yang terjadi dalam organisasi termasuk sekolah sebagai lembaga pendidikan.

\section{Keterampilan Hubungan dengan Manusia (Human Relationship Skill)}

Keterampilan hubungan dengan manusia dalam organisasi pendidikan adalah kemampuan kepala sekolah bekerja sama, berkomunikasi dengan personel sekolah dalam rangka menciptakan suasana saling percaya terhadap program sekolah dan dapat memberikan motivasi untuk meningkatkan kinerja guru. 


\section{Keterampilan Administrasi (Administrative Skill)}

Keterampilan administrasi (Administrative Skill) yaitu keseluruhan proses keterampilan bekerja sama dengan memanfaatkan dan memberdaya segala sumber yang tersedia melalui aktivitas perencanaan, pengorganisasian, pengendalian, penggerakkan, pemotivasian, penyusunan kepegawaian, pengawasan dan supervisi, serta penilaian untuk mewujudkan sistem pendidikan yang efektif dan efesien dan berkualitas.

\section{Keterampilan Tehnikal (Technical skill)}

Keterampilan teknik (technical skill) ialah keterampilan dalam menggunakan pengetahuan, metode, teknik, dan perlengkapan untuk menyelesaikan tugas tertentu.

Keterampilan tehnikal yang diperlukan oleh kepala sekolah adalah yang erat kaitannya dengan aplikasi pengetahuan tentang cara pengelolaan kelas, pengunaan metode pengajaran, tehnik evaluasi siswa, tehnik pembuatan satuan acara pembelajaran, tehnik-tehnik pengelolaan sarana dan prasarana pendidikan, serta tehnik mengarahkan dan membina para guru di sekolah.

\section{Faktor-faktor penghambat dan pendukung Keterampilan Manajerial Kepala Sekolah}

Dalam dunia pendidikan dimana seorang pemimpin adalah manusia, yang tentunya memiliki sifat, karakter, kelebihan dan kekurangan dalam memimpin.

a. Faktor pendukung

Dalam rangka melakukan peran dan fungsinya sebagai manajer, kepala sekolah tentunya memiliki pendukung yang kuat dalam menjalankan kepemimpinannya sebagai kepala sekolah. Adapaun berbagai pendukung keterampilan kepala sekolah yaitu seluruh stakeholder yang ada di sekolah termasuk, guru, siswa dan masyarakat.

b. Faktor penghambat

Adapun berbagai faktor penghambat yang dihadapi oleh Manajerial Kepala Sekolah adalah. Keterbatasan dana dan Keterbatasan tenaga pendidik (kebanyakan honorer)

\section{DAFTAR PUSTAKA}

Helmawati. 2014. Meningkatkan Kinerja Kepala Sekolah/Madrasah Melalui Manajerial Skill. Jakarta: PT. Rinekka Cipta.

H. Siswanto B. 2005. Pengantar Manajemen. Jakarta: PT. Bumi Aksara. Kamaluddin, Undang Ahmad dan Muhammad Alfan. 2010. Etika Manajemen Islam. Bandung: Pustaka Setia. 
Kompri. 2015. Manajemen Pendidikan. Bandung: CV. Alfabeta.

Mardalis. 2010. Metode Penelitian (Suatu Pendekatan Proposal). Cet. 12. Jakarta: PT. Bumi Aksara.

Munawaroh. 2012. Panduan Memahami Metodologi Penelitian. Cet. 1 October, Antimedia.

Pidarta, Made. 2011. Manajemen Pendidikan Indonesia. Jakarta: Rineka Cipta.

Purwanto, M. Ngalim.1987. Ilmu Pendidikan Teoretis dan Praktis. Cet.III. Bandung: Remadja Karya.

Republik Indonesia. 2003. UU No.20 Tahun 2003.Tentang Sistem Pendidikan Nasional. Bandung: Fokusmedia.

Saebani, Beni Ahmad. 2008. Metode Penelitian. Bandung: Pustaka Setia Saefullah, U. 2012. Manajemen Pendidikan Islam. Bandung: CV. Pustaka Setia.

Satori, Djam'an dan Aan Komariah. 2011. Metodologi Penelitian Kualitatif. Bandung: CV. Alfabeta.

Subagyo P, Joko.1991. Metode Penelitian (Dalam Teori dan Praktek). Jakarta: PT. Rineka Cipta.

Sugiyono. 2014. Metode Penelitian Pendidikan (Pendekatan Kuantitatif, Kualitatif, dan R\&D). Bandung: CV. Alfabeta.

Syaifullah, Sagala, 2009. Kemampuan Profesioanl Guru dan Tenaga Pendidikan. Bandung: Alfabeta.

Terry, George R dan Leslie W. Rue. 1992. Dasar-Dasar Manajemen. Jakarta: PT. Bumi Aksara.

Wahyudi. 2012. Kepemimpinan Kepala Sekolah dalam Organisasi Pembelajaran. Bandung: CV. Alfabeta. 